\title{
Characteristics and Outcome of Children Admitted with Sars- Cov-2 Infection: Experiences from a Pediatric Public Hospital in Western India
}

Sudha Rao ( $\nabla$ c_sudha@hotmail.com )

Bai Jerbai Wadia Hospital for Children

Vrushabh Gavali

Bai Jerbai Wadia Hospital for Children

Shakuntala S Prabhu

Bai Jerbai Wadia Hospital or Children

Radhika Mathur

Bai Jerbai Wadia Hospital for Children

Larissa Robert Dabre

Bai Jerbai Wadia Hospital for Children

Sanjay B Prabhu

Bai Jerbai Wadia Hospital for Children

Minnie Bodhanwala

Bai Jerbai Wadia Hospital for Children

\section{Research Article}

Keywords: Pediatric COVID19, Co-morbidities, Mortality predictors, Multisystem inflammatory response syndrome,/Kawasaki like illness (MIS-C/KD)

Posted Date: September 29th, 2020

DOI: https://doi.org/10.21203/rs.3.rs-81068/v1

License: (a) (1) This work is licensed under a Creative Commons Attribution 4.0 International License. Read Full License 


\section{Abstract}

Background

SARS-CoV-2 infection in children is asymptomatic or mildly symptomatic. Clinical characteristics and outcome of children admitted with COVID 19, especially with underlying illnesses, has not been studied.

Objective

To study the clinical characteristics and outcome of children admitted, with SARS-CoV-2 infection, to a paediatric multispecialty hospital in Mumbai, the epicentre of the COVID19 pandemic in India.

Design and Setting

Retrospective observational study of medical records of 969 children admitted between 19 March and 7 August 2020.

Participants

Clinico-demographic characteristics and outcome of COVID 19 positive children admitted during the study period. Variables compared between children who were previously healthy (Group I) and children with comorbidity (Group II).

Main outcome

COVID 19 disease severity characterisation and factors predicting outcome as discharge or death was studied.

Results

$123(71 \mathrm{M})$ tested SARS-CoV-2-positive by RT-PCR with median age of presentation of 3 years [IQR 0.7- 6 years]. $47(38 \%)$ had co-morbidities and were more severely affected $(p=0.0146)$. MIS-C/ KD was common in Group I. Thirty nine (31.7\%) needed intensive care. Fourteen (11.4\%) died. Male sex, respiratory manifestation, pulseox saturation $<94 \%$ at admission, need for ventilation, inotrope, hospital stay of $<10$ days were independent mortality predictors. Regression analysis revealed oxygen saturation $<94 \%$ at admission (OR 35.9, $95 \% \mathrm{Cl} 1.5-856)$ and hospital stay < 10 days (OR $9.1,95 \% \mathrm{Cl} 1.04-99.1)$ as predictors of mortality.

Conclusion

COVID 19 in children although considered mild, presence of co-morbidities causes severe disease. Pulseox saturation $<94 \%$ on admission, hospital stay $<10$ days are predictors of mortality.

\section{Introduction}

Severe acute respiratory syndrome coronavirus 2 (SARS-CoV-2) infection, leading to the pandemic, termed COVID-19 disease by WHO, as of 6 September, 2020, has 21 million confirmed cases and 9,00,000 deaths 
globally and in India, 4,113,811 cases have been confirmed with 70,626 deaths. Mumbai Metropolitan Region (MMR) and the City of Mumbai is the worst affected hotspot in India [1, 2]. After the first pediatric SARS-CoV-2 case, reported on March 16, 2020, in Mumbai, the number of positive cases in children has increased and from the end of April 2020, multisystem inflammatory syndrome/ and Kawasaki-like disease (MIS-C/KD) in association with SARS-CoV-2 infection are diagnosed frequently.

Bai Jerbai Wadia Hospital for Children, Mumbai, a tertiary care, public, specialist hospital, received many children with suspect COVID19 like illnesses from March 19, 2020. Many vulnerable children with co-morbid conditions like heart disease, malnutrition, malignancy, diabetes, chronic kidney disorder, etc. also presented for acute inter current emergencies.

This retrospective study presents the epidemiology, clinical characteristics, treatment and outcome, our experiences, and challenges in the care of neonatal and pediatric cases of SARS-CoV-2 infection from a resource limited, high volume, paediatric public hospital.

\section{Method}

Retrospective medical record review, to conduct analytical cohort study, of all children admitted to the hospital between March 19, when COVID 19 care services were initiated, and August 7, 2020. Approval of institutional ethic committee was obtained.

All children with reverse transcriptase polymerase chain reaction (RT-PCR) for SARS-CoV-2 positive were included in the study.

As per institutional protocol, derived from national guidelines, all children requiring admission were tested by RT-PCR for SARS-CoV-2 from an Indian Council of Medical Research (ICMR) recognized laboratory. Children who tested positive were admitted to the isolation ward specially created as per the Government of India (GOI) guidelines [3]. Historical details and pre-existing co-morbidities were recorded. COVID-19 disease characterization was done according to ICMR guidelines [4].MIS-C and KD were defined as per standard definition for typical or atypical KD and CDC, Atlanta guidelines [5,6]. Institutional protocol of care created based on ICMR /GOI recommendations was followed in all COVID19 positive children. (Table I)

Laboratory investigations and imaging studies were carried at bedside as per protocol. Therapeutic principles included general supportive therapy, active control of fever, and respiratory support with oxygen and/or ventilation as necessary, vasoactive drugs in shock, and active monitoring of organ system dysfunctions. Given the lack of conclusive evidence of specific therapy, the only antiviral used was Remdesivir, in children above 12 years of age with COVID19 pneumonia. It was administered to younger children on compassionate grounds with risk explained and an informed consent taken. Intravenous immunoglobulin, pulse methyl-prednisolone, and anticoagulation with low-molecular-weight heparin were used as per protocol. (Table I)Repeat testing for SARS-CoV-2 PCR and discharge criteria were followed as per ICMR guidelines. (Table I) Time taken to PCR negativity and duration of hospital stay was noted. Treatment outcomes were defined as discharged or died. 
All COVID19 positive children in this cohort were classified based on underlying illnesses. Group I comprised of children who were previously healthy and children in Group II had co-morbidities like heart disease, diabetes, malignancy, malnutrition, hematological conditions, immune compromised state, neurological, surgical/orthopedic conditions, etc. All variables were compared between the two groups.

\section{Statistical Analysis}

Data was entered in MS Excel, and coded and analysed in statistical software STATA, version 10.1, 2011 (Stata Corp. Texas, USA). Descriptive statistics were used to summarize quantitative variables with mean, standard deviation (SD); or median and Inter Quartile Range for some skewed variables. Frequency and percentages were used to summarize categorical variables. Inferential statistics mainly included hypothesis testing procedures like Pearson's Chi-square test for assessing significance of association between outcome (mortality/discharge) and exposure variables/predictors. Binomial test for difference in proportions was also used to compare proportions in sub-groups or categories in two groups. Student's t-test or Mann-Whitney test was performed to assess significance of difference in means or medians in two independent groups. Binary Multiple Logistic Regression model was applied to identify predictors of mortality accounting for the role of other factors, wherein adjusted odds ratio (OR) and 95\% Confidence Intervals (Cl) were estimated. A p-value of $<0.05$ was considered statistically significant for all the comparisons.

\section{Results}

From19 March to 7 August 2020, 969 children were admitted and RT-PCR for SARS-CoV-2 was done in 964. Maximum numbers of admissions were in late June.(Fig 1) Of the 964 tested cases, 123 (12.8\%) were positive including $16(13 \%)$ extramural neonates. Only $5(4.1 \%)$ had a history of travel. Males $(n=77 / 123 ; 57.7 \%)$ were more than females $(n=52 / 123 ; 42.3 \%)$ with a median age at presentation of 3 yrs. (IQR $0.7-6.0)$. Thirty-nine (32\%) children presented between 1 and 5 years of age. (Table 2) Of 123 cases, 76 (62\%) children belonged to Group I and 47 (38\%) children were in Group II. Distribution of various co-morbidities amongst SARS-CoV-2 PCR positive cases is shown in Figure 2.

Children in Group I presented at a younger age (median 1.7 years [IQR 0.5-5.25]) than those in Group II (median 4 years [IQR 0.80- 9]). (Table2) 27 (22\%) children were asymptomatic and 19 (70\%) of them had an underlying co-morbidity. Fever in $24(20 \%)$ or upper or lower respiratory tract symptoms (cough, sore throat, breathlessness) in 30 (24\%) were other common presenting symptoms. Seizures in $13(10 \%)$, gastrointestinal symptoms (vomiting, loose stools, pain abdomen, constipation, distended abdomen) in 15 (12.2\%) were the atypical presentations. Three children (2.4\%) had an abscess/skin and soft tissue infection. Incidentally 6 (5\%) children presented with injuries: head injury due to fall/limb fracture. Characterization of disease severity revealed that children in Group II had more severe COVID19 disease than children in Group I, this difference was statistically significant.(Table II)

On admission, the mean $\pm \mathrm{SD}$ of laboratory parameters including hemoglobin $(10.5 \pm 2.8 \mathrm{gm} / \mathrm{dl})$, complete blood count $(11230 \pm 9271 \mathrm{c} / \mathrm{mm} 3)$, and platelet count $(310437 \pm 156366 \mathrm{Lac} / \mathrm{mm} 3)$ were normal. The mean Neutrophil: Lymphocyte ratio although higher in Group II ( $4.5 \pm 5.1)$ than Group I $(2.6 \pm 3.6)$, the difference was not significant.Chest radiograph done in 114 (93\%) cases, 91 (80\%) was normal. Consolidation $(n=6 / 114 ; 5 \%)$, 
pleural effusion $(n=7 / 114 ; 6 \%)$ bilateral haziness $(n=6 / 114 ; 5 \%)$, cardiomegaly $(n=3 / 114 ; 2.6 \%)$, and mediastinal mass ( $n=1 / 114 ; 0.01 \%$ ) were other observed features.

Eighty-four (68.3\%) children did not need oxygen support. Of the other 39 (31.7\%) cases, 20 (51.2\%) needed free flow oxygen, 19 (15.4\%) on mechanical ventilation which was non-invasive in 6 (31.5\%) and invasive in 13 $(68.5 \%)$ children. Larger number of children in Group I $(n=13 / 19)$ required ventilator care. Vasoactive drugs were required in 17 (14\%) cases, of which 11 belonged to Group I. (Table II)

Thirty-nine (32\%) children needed intensive care which was not different between Group I $(\mathrm{n}=24 / 76 ; 31.6 \%)$ and Group II ( $n=15 / 47 ; 32 \%)$. Severe COVID19 pneumonia ( $n=10 / 39 ; 25.6 \%)$, circulatory collapse $(n=5 / 39$; $13 \%)$, MIS-C/KD ( $n=8 / 39 ; 23 \%)$, worsening of the underlying disease ( $n=16 / 39 ; 41 \%)$ were the indications for intensive care. Remdesivir was given to two children with severe COVID19 pneumonia.

While compiling the study, 4 children were still admitted. The median duration of PCR negativity was 5 days (range, 3-15 days). Most patients were discharged ( $n=105 / 119 ; 88 \%)$ with a median length of hospital stay of 9 days (range, $4-17$ days), which did not differ significantly between Groups I and II. (Table II)

There were $14(11.4 \%)$ deaths of which $3(21.5 \%)$ were neonates and 5 (36\%) were more than 8 years of age. On univariate analysis, male sex (OR, 4.57; 95\% Cl, 1.1-26.4; $\mathrm{p}=0.017)$, pulse oximeter saturation<94\% at admission (OR, 8; 95\% Cl, 20-31.6; $\mathrm{p}=0.001)$, abnormal chest $x$-ray (OR, 7.2; 95\% Cl, 1.89-29.7; $\mathrm{p}=0.001)$, need for respiratory support $(\mathrm{OR}, 19.2 ; 95 \% \mathrm{Cl}, 3.8-182.5 ; \mathrm{p}=0.001)$, need for vasoactive support (OR, 19.5; $95 \% \mathrm{Cl}, 2.3-38.5 ; \mathrm{p}=0.001)$, need for intensive care $(\mathrm{OR}, 18.2 ; 95 \% \mathrm{Cl}, 3.6-173.2 ; \mathrm{p}=0.001)$, and the duration of hospital stay $(\mathrm{OR}, 7 ; 95 \% \mathrm{Cl}, 0.8-322.6 ; \mathrm{p}=0.04)$ were mortality predictors. On logistic regression, pulseox saturation $<94 \%$ at admission $(\mathrm{OR}, 9.1 ; 95 \% \mathrm{Cl}, 1.04-99.1)$ and hospital stay of less than 9 days (OR, 35.9; $95 \%$ $\mathrm{Cl}, 1.5-856.0)$ were predictors of mortality. (Table III)

Challenges and Experiences

Lack of definite pediatric guidelines necessitated the treatment and care strategies to be adapted from adult , ICMR/GOI guidelines [4]. It was a challenge to devise an institutional protocol of care not only for children but also their caretakers and health care workers (HCW) that needed frequent updating and scrutiny. Segregating care areas, logistic support, reallocating manpower, redistributing medical equipments, and redesigning the services to provide a dedicated, high standard of care at affordable price. Each specialty services had to improvise care and protocol to include home monitoring, telephonic consultation, clustering of care during hospital visit. Cross specialty consults and investigations were coordinated so as to minimize intervention and hospital visits.

\section{Discussion}

COVID19 is a global health crisis. To our knowledge, this is the largest, in-patient pediatric COVID19 study from pediatric multispecialty public hospital in India. The study highlights the demographic features, clinical characteristics, disease progression, and outcome of 123 children admitted with COVID19. As this study enrolled children who were admitted to the hospital, the data likely represents individuals from the moderate to severe end of the disease spectrum. 
As soon as the first pediatric COVID19 case was reported in March 2020, in Mumbai, a dedicated COVID care area, personnel, equipment, and protocol were organised on an emergency mode. Global data suggested that children were infected early during community transmission phase and hence a low threshold of suspicion was followed for COVID 19 testing. As the pandemic rapidly evolved and emerging evidence suggested that children were largely asymptomatic or mildly symptomatic, we adopted screening for SARS-CoV-2 in all admissions as the entire city had become a hotspot. In the initial few months, COVID19 cases were only from Mumbai. As the lockdown was slightly relaxed, more children from the Mumbai Metropolitan Region were admitted.

Of 969 children admitted, RT-PCR for SARS-CoV-2 was performed in 964. Of these, 123 tested positive, a positivity rate of $12.7 \%$ lesser than the reported overall positive rate of $20.8 \%$ until 7 August 2020 .

There were 76 (62\%) cases in Group I comprising of previously healthy children and 47 (38\%) in Group II who had underlying illness. (Figure 2) In an earlier study from Columbia Pediatric COVID19 management group comorbidities were defined as Obesity, Asthma, Infancy or Immune suppression were studied [7].

Median age of presentation was 3 years, older children (>10 years of age) were more in Group II. Twenty seven $(21.7 \%)$ children were asymptomatic. Initial studies from China reported $4.1-50 \%$ cases to be asymptomatic, while 58\% were asymptomatic in a study from Pune[2-4]. The wide variation could be attributed to the difference in COVID19 testing protocol.

As seen in other series, fever and respiratory symptoms were the common presenting symptoms[8-10,12,13]. Atypical presentations like seizures (10.6\%) and gastrointestinal symptoms (12.2\%) were more common as compared to other studies.[7,9,12,14] Seizure and diarrhea as presenting symptoms was more common in Group I.

COVID19 disease severity characterization revealed mildly symptomatic children were significantly more in Group I $(n=50 / 76,66 \%)$ than Group II $(n=4 / 47,8.5 \%$; $p=0.0001)$ and moderate to severe COVID19 was significantly more in Group II $(n=22 / 47,47 \%)$ than Group I $(n=4 / 76,5.3 \% ; p=0.0001)$. Children with an underlying illness had severe disease. Interestingly, the immunological consequence of COVID19, the MIS-C/KD ( $n=11 / 123 ; 9 \%)$ was found more in Group I $(n=8 / 76,10.5 \%)$ than Group II ( $n=3 / 47,6.4 \%)$. Interestingly, presence of co morbidity, dysregulates or blunts the immunological host responses causing severe infection but is unable to mount a hyperinflammatory immune response like MIS-C/KD.

Though chest radiograph is not considered the best modality to diagnose COVID19 pneumonia and unilateral or bilateral peripheral shadows and/or ground glass opacities have been described but pleural effusion is rare[15]. In this series, 12 cases had consolidation/bilateral haziness and 7 had pleural effusion.

Thirty-nine (32\%) cases needed intensive care. Severe COVID19 pneumonia, circulatory collapse, MIS-C/KD, and worsening of underlying disease were the common indications. Need for intensive care in our series is higher than reported in literature[16]. This could be because we had more vulnerable children with underlying illness and severe COVID19 disease requiring intensive care. Although adult studies suggest presence of comorbidities as an important predictor of need for intensive care[17,18], this was not found in our study. Children requiring mechanical ventilation (15.5\%) were fewer than those in the cohort from USA $[7,19]$ which could be due to more children non respiratory presentations. There was no significant difference between the two groups with regard to length of hospital stay or disease outcome. (Table II) 
A systematic review in adults concluded that co-morbidities like Hypertension, Cardiovascular disease, Diabetes, and chronic renal diseases were significantly associated with mortality [20]. A study of children from the European cohort concluded that neonates, male sex, pre-existing medical conditions, fever, lower respiratory tract infection, radiological changes of pneumonia or ARDS, and viral co-infection were associated with more severe course on univariate analysis; however, the study did not compare these parameters to mortality[14]. In our cohort, male sex, hypoxia (Sp02 $<94 \%$ ) on admission, need for respiratory support, inotropes, intensive care, length of hospital stay $<10$ days was significantly associated with mortality on univariate analysis. Male gender has been associated with a higher risk of severe disease and mortality because of higher ACE-2 receptor expression [21]. On regression analysis ,SpO2 $<94 \%$ on admission and length of hospital stay of $<10$ days were predictors of mortality and not the presence of co-morbidities. Similar experience from adult studies has shown mortality within 1 to 2 weeks of ICU admission [17]. To our knowledge, no pediatric study mentioning predictors of mortality has been conducted to date.

As a retrospective study, certain important parameters like onset of symptoms from day of contact, source of infection, and exact duration of COVID19 RT-PCR positivity in all children could not be assessed.

\section{Conclusion}

Contrary to belief that pediatric COVID19 is a mild illness, children with co morbidity are more vulnerable and manifest with severe disease. Immunologic manifestations (MIS-C/KD) are more in previously well children. Male sex, hypoxia on admission, need for ventilator support, inotrope, intensive care, hospital stay of less than 10 days are predictors of risk of mortality. We suggest universal testing with RT PCR for SARS-CoV-2 in all children admitted to hospitals to identify and segregate the cases, provide protocol based care, characterize the severity, initiate prompt treatment and improve outcome.

\section{Key Message:}

What is already known?

1. Pediatric COVID 19 cases are largely asymptomatic or mildly symptomatic.

2. Neonates, male gender, pre-existing medical conditions, fever, lower respiratory tract infection, radiological changes suggestive of pneumonia or ARDS, and viral co-infection were associated with more severe course.

What this study adds?

1. Children with underlying medical illnesses have significantly severe COVID19 disease

2. Immunological presentation of COVID19 like MIS-C/KD is more in children without associated co morbidity/illness.

3. Male gender, hypoxia (Sp02 <94\%) on admission, need for respiratory support, need for vasoactive drugs, ICU care, and length of hospital stay of $<10$ days is significantly associated with mortality.

\section{Declarations}


Disclaimer None

Funding- None

Conflict of interest - None

Institutional Ethics Committee- Bai Jerbai Wadia Hospital for Children approval obtained wide letter dated 26th August 2020, Ref No IEC-BJWHC/ 89/2020 of project no IEC-BJWHC/AP/2020/29-version2

Author contributions -

SR, SSP, SBP - conceived , designed the study ,finalised the manuscript

SR, VG, RM, LRD, SBP, SSP, MB - data collection, data analysis

SR, VG, RM, LRD, SSP, SBP - Literature search, interpretation of data, writing manuscript

\section{References}

1. WHO. Timeline: WHO's COVID-19 response [Internet]. World Health Organization. 2020 [cited 2020 Aug 27 ]. Available from: https://www.who.int/emergencies/diseases/novel-coronavirus-2019/interactive-timeline

2. Soni B. Coronavirus in Mumbai: Ward-wise breakdown of COVID-19 cases issued by BMC as of July 10. Freepressjournal [Internet]. 2020 Aug 8 [cited 2020 Aug 27];1-10. Available from:

https://www.freepressjournal.in/mumbai/coronavirus-in-mumbai-ward-wise-breakdown-of-covid-19-casesissued-by-bmc-on-august-8

3. National Centre for Disease Control. COVID -19 Outbreak Guidelines for Setting up. New Delhi (IN): Ministry of Health \& Family Welfare 2020; 2020. 15 p.

4. Diretorate General of Health Services. Revised National Clinical Management Guideline for COVID-19. New Delhi (IN): Ministry of Health \& Family Welfare; 2020. 2-3 p.

5. Jiang L, Tang K, Levin M, Irfan O, Morris SK, Wilson K, et al. COVID-19 and multisystem inflammatory syndrome in children and adolescents. Lancet Infect Dis [Internet]. 2020;3099(20). Available from: http://www.ncbi.nlm.nih.gov/pubmed/32818434\%0Ahttp://www.pubmedcentral.nih.gov/articlerender.fcgi? artid=PMC7431129

6. Singh S, Jindal AK, Pilania RK. Diagnosis of Kawasaki disease. Int J Rheum Dis. 2018;21(1):36-44.

7. Zachariah P, Zachariah P, Johnson CL, Johnson CL, Halabi KC, Ahn D, et al. Epidemiology, Clinical Features, and Disease Severity in Patients with Coronavirus Disease 2019 (COVID-19) in a Children's Hospital in New York City, New York. JAMA Pediatr. 2020;2019:E202430.

8. Dong Y, Dong Y, Mo X, Hu Y, Qi X, Jiang F, et al. Epidemiology of COVID-19 among children in China. Vol. 145, Pediatrics. 2020. p. e20200702.

9. Qiu H, Wu J, Hong L, Luo Y, Song Q, Chen D. Clinical and epidemiological features of 36 children with coronavirus disease 2019 (COVID-19) in Zhejiang, China: an observational cohort study. Lancet Infect Dis [Internet]. 2020;20(6):689-96. Available from: http://dx.doi.org/10.1016/S1473-3099(20)30198-5 
10. Song W, Li J, Zou N, Guan W, Pan J, Xu W. Clinical features of pediatric patients with coronavirus disease (COVID-19). J Clin Virol. 2020;127(January).

11. Sarangi B, Reddy VS, Oswal J, Malshe N, Patil A, Chakraborty M, et al. Epidemiological and clinical characteristics of COVID-19 in Indian children in the initial phase of the pandemic: A cross-sectional study. 2020;1-15.

12. Zhang C, Gu J, Chen Q, Deng N, Li J, Huang L, et al. Clinical and epidemiological characteristics of pediatric SARS-CoV-2 infections in China: A multicenter case series. PLoS Med. 2020;17(6):e1003130.

13. Mantovani A, Rinaldi E, Zusi C, Beatrice G, Saccomani MD, Dalbeni A. Coronavirus disease 2019 (COVID19) in children and/or adolescents: a meta-analysis [Internet]. Vol. 2019, Pediatric Research. Springer US; 2020. Available from: http://dx.doi.org/10.1038/s41390-020-1015-2

14. Götzinger F, Santiago-García B, Noguera-Julián A, Lanaspa M, Lancella L, Calò Carducci FI, et al. COVID-19 in children and adolescents in Europe: a multinational, multicentre cohort study. Lancet Child Adolesc Heal. 2020;4642(20):1-9.

15. Foust AM, Phillips GS, Chu WC, Daltro P, Das KM, Garcia-Peña P, et al. International Expert Consensus Statement on Chest Imaging in Pediatric COVID-19 Patient Management: Imaging Findings, Imaging Study Reporting and Imaging Study Recommendations. Radiol Cardiothorac Imaging. 2020;2(2):e200214.

16. Kim L, Whitaker M, O’Halloran A, Kambhampati A, Chai SJ, Reingold A, et al. Hospitalization Rates and Characteristics of Children Aged < 18 Years Hospitalized with Laboratory-Confirmed COVID-19 - Morb Mortal Wkly Rep. 2020;69(32):1081-8.

17. Yang X, Yu Y, Xu J, Shu H, Xia J, Liu H, et al. Clinical course and outcomes of critically ill patients with SARS-CoV-2 pneumonia in Wuhan, China: a single-centered, retrospective, observational study. Lancet Respir Med [Internet]. 2020;8(5):475-81. Available from: http://dx.doi.org/10.1016/S2213-2600(20)300795

18. Ravikumar N, Nallasamy K, Bansal A, Kumar Angurana S, Gv B, Sundaram M, et al. Novel Coronavirus 2019 (2019-nCoV) Infection: Part I-Preparedness and Management in the Pediatric Intensive Care Unit in Resource-limited Settings. INDIAN Pediatr [Internet]. 2020;57(4):324-34. Available from: https://indianpediatrics.net/apr2020/324.pdf

19. Shekerdemian LS, Mahmood NR, Wolfe KK, Riggs BJ, Ross CE, McKiernan CA, et al. Characteristics and Outcomes of Children with Coronavirus Disease 2019 (COVID-19) Infection Admitted to US and Canadian Pediatric Intensive Care Units. JAMA Pediatr. 2020;2019:1-6.

20. Tian W, Jiang W, Yao J, Nicholson CJ, Li RH, Sigurslid HH, et al. Predictors of mortality in hospitalized COVID-19 patients: A systematic review and meta-analysis. Journal of Medical Virology. 2020. p. 1-9.

21. Yuki K, Fujiogi M, Koutsogiannaki S. COVID-19 pathophysiology: A review. Clin Immunol. 2020;215(January):e108427.

\section{Tables}

Table I BAI JERBAI WADIA HOSPITAL FOR CHILDREN, MUMBAI PEDIATRIC COVID CARE PROTOCOL* 


\begin{tabular}{|l|l|l|l|}
\hline $\begin{array}{l}\text { CLINICAL } \\
\text { CRITERIA }\end{array}$ & \multicolumn{3}{|c|}{ DISEASE SEVERITY } \\
\hline & MILD & MODERATE & SEVERE \\
\hline $\begin{array}{l}\text { Pulse ox } \\
\text { SpO2 }\end{array}$ & $>94 \%$ in room air & $90-94 \%$ in room air & $<90 \%$ in room air \\
\hline $\begin{array}{l}\text { Respiratory } \\
\text { Rate }\end{array}$ & No Tachypnea & Mild Tachypnea & Severe Tachypnea \\
\hline Chest Xray & No Pneumonia & Pneumonia & Severe Pneumonia \\
\hline LABORATORY TESTS & $<3.2$ & $>3.2$ & $>5.5$ \\
\hline NLR & $<40$ & $40-125$ & $>125$ \\
\hline CRP (mg/L) & $<500$ & $>500$ & $>800$ \\
\hline $\begin{array}{l}\text { Serum Ferritin } \\
\text { (mg/dl) }\end{array}$ & $<$ & $>0.5$ & $>1.0$ \\
\hline D-Dimer ( $\mu$ g/L) & $<0.5$ & $300-400$ & $>400$ \\
\hline LDH (U/L) & $<300$ & $4.8-50$ & $>80$ \\
\hline IL-6 (pg/ml) & $<4.8$ & $>28$ & $>28$ \\
\hline $\begin{array}{l}\text { Troponin I } \\
\text { (ng/L) }\end{array}$ & Normal & \multicolumn{3}{|l|}{} \\
\hline
\end{tabular}

TREATMENT

\begin{tabular}{|c|c|c|c|}
\hline Routine & $\begin{array}{l}\text { Paracetamol } \\
15 \mathrm{mg} / \mathrm{kg}\end{array}$ & Paracetamol $15 \mathrm{mg} / \mathrm{kg}$ & Paracetamol $15 \mathrm{mg} / \mathrm{kg}$ \\
\hline & $\begin{array}{l}\text { T.Vitamin C } \\
250 \mathrm{mg} \mathrm{OD}\end{array}$ & T.Vitamin C 250mg BD & T.Vitamin C 250mg BD \\
\hline & $\begin{array}{l}\text { Zinc } \\
2 \mathrm{mg} / \mathrm{kg} \text { for } \\
7 \text { days }\end{array}$ & Zinc $2 \mathrm{mg} / \mathrm{kg}$ for 7 days & Zinc $2 \mathrm{mg} / \mathrm{kg}$ for 7 days \\
\hline & $\begin{array}{l}\text { Vitamin D } \\
60 \mathrm{~K} \text { stat }\end{array}$ & Vitamin D 60K stat & Vitamin D 60K stat \\
\hline Fluids & $\begin{array}{l}\text { Adequate } \\
\text { hydration } \\
\text { oral }\end{array}$ & Adequate hydration iv fluids & Conservative Iv fluids \\
\hline Anti viral & & \multicolumn{2}{|c|}{$\begin{array}{l}\text { Inj. Remdesivir in children }>12 \text { yrs old. Younger age on } \\
\text { compassionate grounds with informed consent }\end{array}$} \\
\hline Anticoagulation & None & LMWH $1 \mathrm{mg} / \mathrm{kg}$ OD & \multirow{2}{*}{$\begin{array}{l}\text { LMWH } 1 \mathrm{mg} / \mathrm{kg} \text { BD } \\
30 \mathrm{mg} / \mathrm{kg} \text { for } 3 \text { days and taper } \\
\text { over } 10-14 \text { days }\end{array}$} \\
\hline $\begin{array}{l}\text { Steroids } \\
\text { (Methyl- } \\
\text { prednisolone) }\end{array}$ & None & $\begin{array}{l}10 \mathrm{mg} / \mathrm{kg} \text { for } 2 \text { days and taper } \\
\text { over } 5 \text { days }\end{array}$ & \\
\hline Oxygen Support & $\begin{array}{l}\text { Not } \\
\text { required }\end{array}$ & Target Spo2 of 92-96\% & Target SpO2 of $90 \%$ \\
\hline & & $\begin{array}{l}\text { Nasal prongs }(41 / \mathrm{min}) \\
\text { Face Mask }(5-10 \mathrm{l} / \mathrm{min}) \\
\text { NRM }(10-15 \mathrm{~L} / \mathrm{min}) \\
\text { HHHFNC }(2 \mathrm{~L} / \mathrm{kg}) \\
\text { CPAP }(\text { TV } 6 \mathrm{ml} / \mathrm{kg}) \\
\text { PEEP } 5-15\end{array}$ & $\begin{array}{l}\text { NRM }(10-15 \mathrm{~L} / \mathrm{min}) \\
\text { HHHFNC }(2 \mathrm{~L} / \mathrm{kg}) \\
\text { CPAP }(\text { TV } 6 \mathrm{ml} / \mathrm{kg}) \\
\text { PEEP } 5-15 \\
\text { Target PP } 30 \mathrm{~cm} \mathrm{H}_{2} \mathrm{O} \\
\text { MV (ARDS protocol) }\end{array}$ \\
\hline
\end{tabular}




\begin{tabular}{|c|c|c|c|}
\hline & & \multicolumn{2}{|l|}{ Target PP $30 \mathrm{~cm} \mathrm{H} 2 \mathrm{O}$} \\
\hline \multicolumn{2}{|c|}{$\begin{array}{l}\text { Cytokine Storm: } \\
\text { Reappearance } \\
\text { of fever } \\
\text { Tachycardia } \\
\text { High IL-6levels }\end{array}$} & $\begin{array}{l}\text { Inj.Tocilizumab } \\
\text { (Ideal time Day 8- Day } 10 \text { of } \\
\text { illness) IV slow infusion in } \\
100 \mathrm{ml} \text { NS over } 1 \text { hour. }\end{array}$ & $\begin{array}{l}\text { Inj.Tocilizumab } \\
\text { (Ideal time Day } 8 \text { - Day } 10 \text { of } \\
\text { illness) IV slow infusion in } \\
100 \mathrm{ml} \text { NS over } 1 \text { hour. }\end{array}$ \\
\hline \multicolumn{4}{|l|}{ MONITORING } \\
\hline CBC/RFT/LFT & Baseline & Every 2 days & Daily \\
\hline D dimer & Baseline & Every 4 days & Every 2 days \\
\hline Chest Xray & & If clinical deterioration & As per standard of \\
\hline \multicolumn{4}{|c|}{ DISCHARGE CRITERIA } \\
\hline & $\begin{array}{l}10 \text { days from } \\
\text { onset of } \\
\text { symptoms }\end{array}$ & $\begin{array}{l}10 \text { days from onset of } \\
\text { symptoms }\end{array}$ & Clinical recovery \\
\hline
\end{tabular}

CBC -Complete Blood count, NLR - Neutrophil Lymphocyte Ratio, IL-6 -Interleukin6,LFT -Liver Function Test, RFTRenal Function Test, LWMH -Low Molecular Weight Heparin, NRM-Non Re breathing Mask, HHHFNC-Heated Humidified High Flow Nasal Cannula, CPAP- Continuous Positive Airway Pressure, PEEP-Positive End Expiratory Pressure, PP-Partial Pressure, MV-Mechanical Ventilation ,ARDS-Adult Respiratory Distress Syndrome *.National Centre for Disease Control. COVID -19 Outbreak Guidelines for Setting up. New Delhi (IN): Ministry of Health \& Family Welfare 2020; 2020. 15 p. **Diretorate General of Health Services. Revised National Clinical Management Guideline for COVID-19. New Delhi (IN) : Ministry of Health \& Family Welfare; 2020. 2-3 p. 


\begin{tabular}{|c|c|c|c|c|}
\hline & $\begin{array}{l}A L L \\
N=123(\%)\end{array}$ & $\begin{array}{l}\text { Group I } \\
N=76(62)\end{array}$ & $\begin{array}{l}\text { Group II } \\
N=47\end{array}$ & $\begin{array}{l}P \\
\text { Value }\end{array}$ \\
\hline Male & $71(57.7)$ & $43(56.6)$ & $28(59.6)$ & 0.744 \\
\hline Female & $52(42.3)$ & $33(43.4)$ & $19(40.4)$ & \\
\hline $\begin{array}{l}\text { Age of presentation in years } \backslash \text { Median } \\
\text { (IQR) }\end{array}$ & $3.0(0.7-6.0)$ & $1.7(0.5-5.25)$ & $4.0(0.8-9.0)$ & 0.0521 \\
\hline \multicolumn{5}{|l|}{ Age wise distribution } \\
\hline$<1$ mo of age & $16(13.0)$ & & $4(8.5)$ & 0.2436 \\
\hline $1 \mathrm{mo}-1 \mathrm{yr}$ & $31(25.2)$ & $12(15.8)$ & $11(23.4)$ & 0.7178 \\
\hline $1 \mathrm{yr}-5 \mathrm{yr}$ & $39(31.7)$ & $20(26.3)$ & $14(29.8)$ & 0.7189 \\
\hline $5-10 y r$ & $26(21.1)$ & $25(32.9)$ & & 0.6709 \\
\hline \multirow[t]{2}{*}{$>10 y r$} & $11(8.9)$ & $17(22.4)$ & $9(19.2)$ & 0.0018 \\
\hline & & $2(2.6)$ & $9(19.2)$ & \\
\hline \multicolumn{5}{|l|}{ Symptoms at presentation } \\
\hline Asymptomatic & 27 (21.9) & $8(13.2)$ & $19(36.2)$ & 0.0027 \\
\hline Fever & $24(19.5)$ & $16(21.0)$ & $8(17.0)$ & 0.5836 \\
\hline Upper respiratory & $5(4.1)$ & $3(3.9)$ & $2(4.3)$ & 0.9330 \\
\hline Lower respiratory & $25(20.3)$ & $18(23.7)$ & 7 (14.9) & 0.2391 \\
\hline Gastrointestinal & $15(12.2)$ & $12(15.8)$ & $3(6.4)$ & 0.1214 \\
\hline Seizures & $13(10.6)$ & $12(15.8)$ & $1(2.1)$ & 0.0166 \\
\hline Others & $14(11.4)$ & $5(6.6)$ & $9(19.2)$ & 0.0329 \\
\hline $\begin{array}{l}\text { Pulse oximeter on admission } \\
\text { SpO2 (\%) mean, sd }\end{array}$ & $95.8,5.5$ & $94.7,7.1$ & $96.5,4.1$ & 0.093 \\
\hline Radiological abnormality & All $(n=114)$ & Group I & Group II $(\mathrm{n}=$ & \\
\hline Abnormal Xray chest & $23(20)$ & $(n=73)$ & 41) & 0.744 \\
\hline \multirow[t]{2}{*}{ Normal Xray chest } & $91(80)$ & $16(22.0)$ & $7(27.7)$ & \\
\hline & & $57(78.0)$ & $34(72.3)$ & \\
\hline $\begin{array}{l}\text { Laboratory Evaluation } \\
(\text { mean ,sd) }\end{array}$ & All $(n=118)$ & $\begin{array}{l}\text { Group I } \\
(\mathrm{n}=73)\end{array}$ & $\begin{array}{l}\text { Group II } \\
(\mathrm{n}=45)\end{array}$ & \\
\hline $\mathrm{Hb}(\mathrm{gm} / \mathrm{dl})$ & $10.5,2.8$ & $10.6,2.9$ & $10.2,2.7$ & 0.459 \\
\hline Total Leucocyte count ( c/mm3) & 11230,9271 & 11156,6898 & 11350,12274 & 0.912 \\
\hline
\end{tabular}




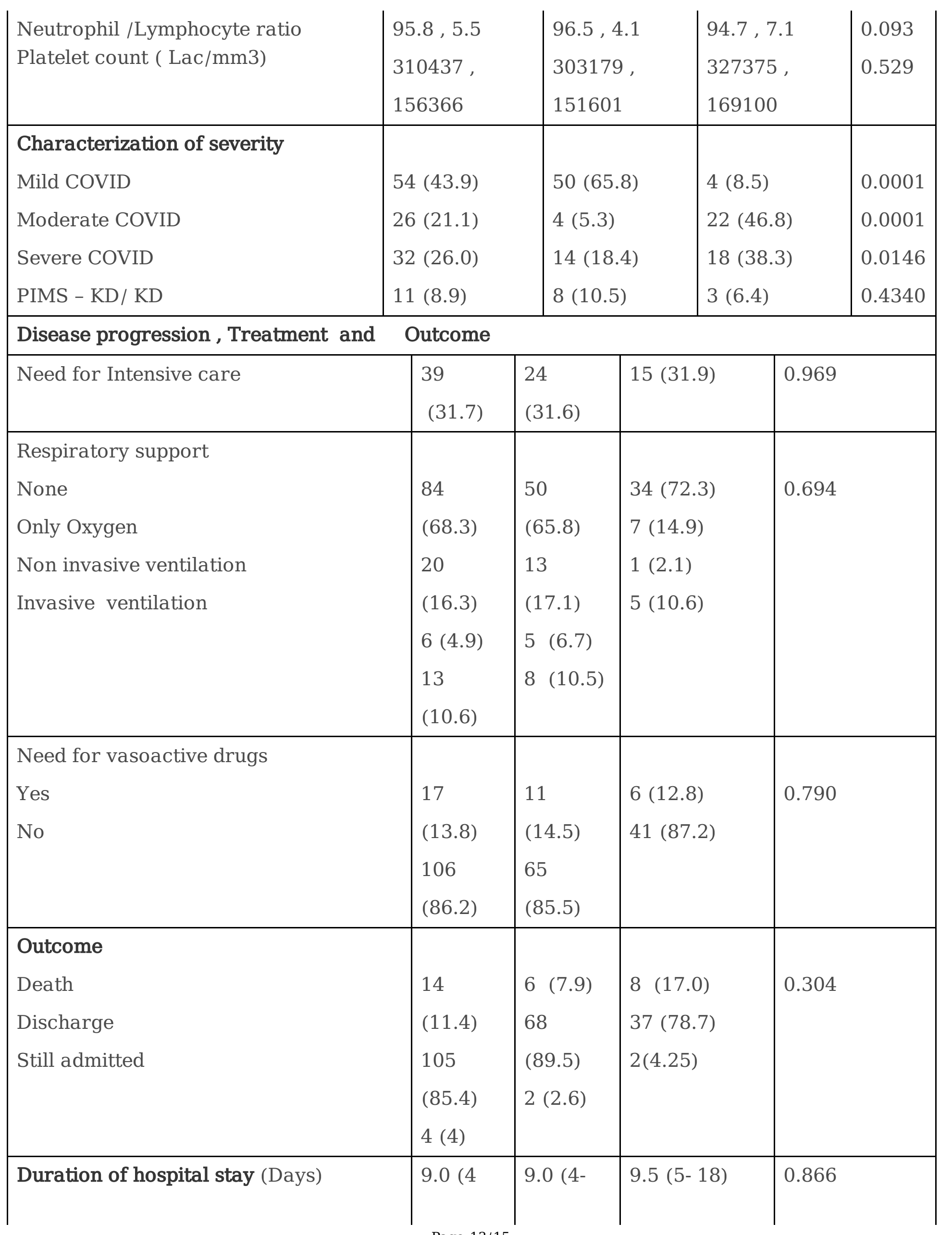


Numbers shown in parenthesis are percentages

Table III Predictors of Outcome

\begin{tabular}{|c|c|c|c|c|c|c|c|c|}
\hline Factors & $\begin{array}{l}\mathrm{De} \\
(\mathrm{n} \\
\mathrm{Nu}\end{array}$ & $\%$ & $\begin{array}{l}\text { Dis } \\
(n= \\
N u r\end{array}$ & $\begin{array}{l}\text { arge } \\
5) \\
\text { er }\end{array}$ & $\%$ & $P$ value & OR & $95 \% C I$ \\
\hline $\begin{array}{l}\text { Age at presentation } \\
</=\quad 3 \text { years } \\
>3 \text { years }\end{array}$ & $\begin{array}{l}7 \\
7\end{array}$ & $\begin{array}{l}50 \\
50\end{array}$ & $\begin{array}{l}56 \\
49\end{array}$ & $\begin{array}{l}88.9 \\
87.5\end{array}$ & & 0.845 & 0.88 & $0.24-3.15$ \\
\hline $\begin{array}{l}\text { SEX } \\
\text { Male } \\
\text { Female }\end{array}$ & $\begin{array}{l}11 \\
3\end{array}$ & $\begin{array}{l}78.6 \\
21.4\end{array}$ & $\begin{array}{l}58 \\
47 \\
\end{array}$ & $\begin{array}{l}55.2 \\
44.8 \\
\end{array}$ & & 0.017 & 4.52 & $1.10-26.4$ \\
\hline $\begin{array}{l}\text { Symptoms } \\
\text { Asymptomatic } \\
\text { Respiratory symptoms } \\
\text { Others }\end{array}$ & $\begin{array}{l}0 \\
10 \\
4\end{array}$ & $\begin{array}{l}0.0 \\
71.4 \\
28.6\end{array}$ & $\begin{array}{l}27 \\
41 \\
37\end{array}$ & $\begin{array}{l}25.7 \\
39.1 \\
35.2 \\
\end{array}$ & & 0.034 & - & - \\
\hline $\begin{array}{l}\text { Travel history } \\
\text { Yes } \\
\text { No }\end{array}$ & $\begin{array}{l}0 \\
14\end{array}$ & $\begin{array}{l}0.0 \\
100.0\end{array}$ & $\begin{array}{l}5 \\
99 \\
\end{array}$ & $\begin{array}{l}4.8 \\
95.2 \\
\end{array}$ & & 0.402 & - & - \\
\hline $\begin{array}{l}\text { X ray chest } \\
\text { Normal } \\
\text { Abnormal } \\
\text { Not done }\end{array}$ & $\begin{array}{l}5 \\
9 \\
0\end{array}$ & $\begin{array}{l}35.7 \\
64.3\end{array}$ & $\begin{array}{l}82 \\
14 \\
9\end{array}$ & $\begin{array}{l}80.0 \\
20.0\end{array}$ & & 0.001 & 7.2 & $1.89-29.74$ \\
\hline $\begin{array}{l}\text { Pulse ox at admission } \\
\text { Abnormal }(<94 \%) \\
\text { Normal }(>/=94 \%)\end{array}$ & $\begin{array}{l}8 \\
6 \\
\end{array}$ & $\begin{array}{l}57.1 \\
42.9 \\
\end{array}$ & $\begin{array}{l}15 \\
90 \\
\end{array}$ & $\begin{array}{l}14.3 \\
85.7 \\
\end{array}$ & & 0.001 & 8.0 & $2.0-31.6$ \\
\hline $\begin{array}{l}\text { Respiratory support } \\
\text { Yes } \\
\text { No } \\
\end{array}$ & $\begin{array}{l}12 \\
2\end{array}$ & \begin{tabular}{|l|}
85.7 \\
14.3 \\
\end{tabular} & $\begin{array}{l}25 \\
80 \\
\end{array}$ & $\begin{array}{l}23.8 \\
76.2 \\
\end{array}$ & & 0.001 & 19.2 & 3.8- 182.5 \\
\hline $\begin{array}{l}\text { Use of Vasoactive drugs } \\
\text { Yes } \\
\text { No }\end{array}$ & $\begin{array}{l}7 \\
7\end{array}$ & $\begin{array}{l}50.0 \\
50.0\end{array}$ & $\begin{array}{l}10 \\
95\end{array}$ & $\begin{array}{l}9.5 \\
90.5\end{array}$ & & 0.001 & 19.5 & 2.3- 38.5 \\
\hline $\begin{array}{l}\text { Need for intensive care } \\
\text { Yes } \\
\text { No }\end{array}$ & $\begin{array}{l}12 \\
2\end{array}$ & $\begin{array}{l}85.7 \\
14.3\end{array}$ & $\begin{array}{l}26 \\
79\end{array}$ & $\begin{array}{l}24.8 \\
75.2\end{array}$ & & 0.001 & 18.2 & 3.6- 173.2 \\
\hline $\begin{array}{l}\text { Duration of hospital stay } \\
\text { Up to } 9 \text { days } \\
\text { More than 9days }\end{array}$ & $\begin{array}{l}7 \\
1\end{array}$ & $\begin{array}{l}87.5 \\
12.5\end{array}$ & $\begin{array}{l}43 \\
43\end{array}$ & $\begin{array}{l}50.0 \\
50.0\end{array}$ & & 0.042 & 7.0 & $0.8-322.6$ \\
\hline
\end{tabular}

\section{Figures}




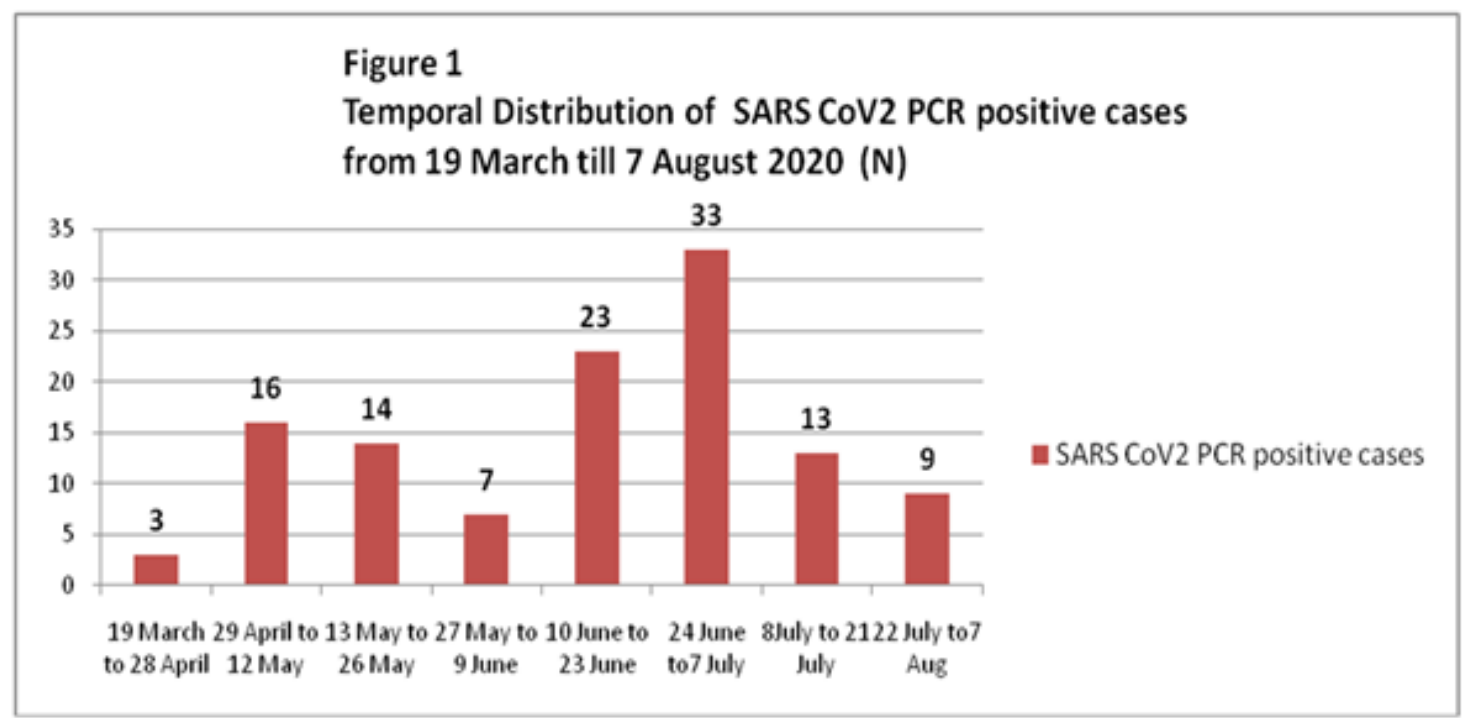

\section{Figure 1}

Temporal Distribution of SARS CoV2 PCR positive cases from 19 March till 7 August 2020 (N)

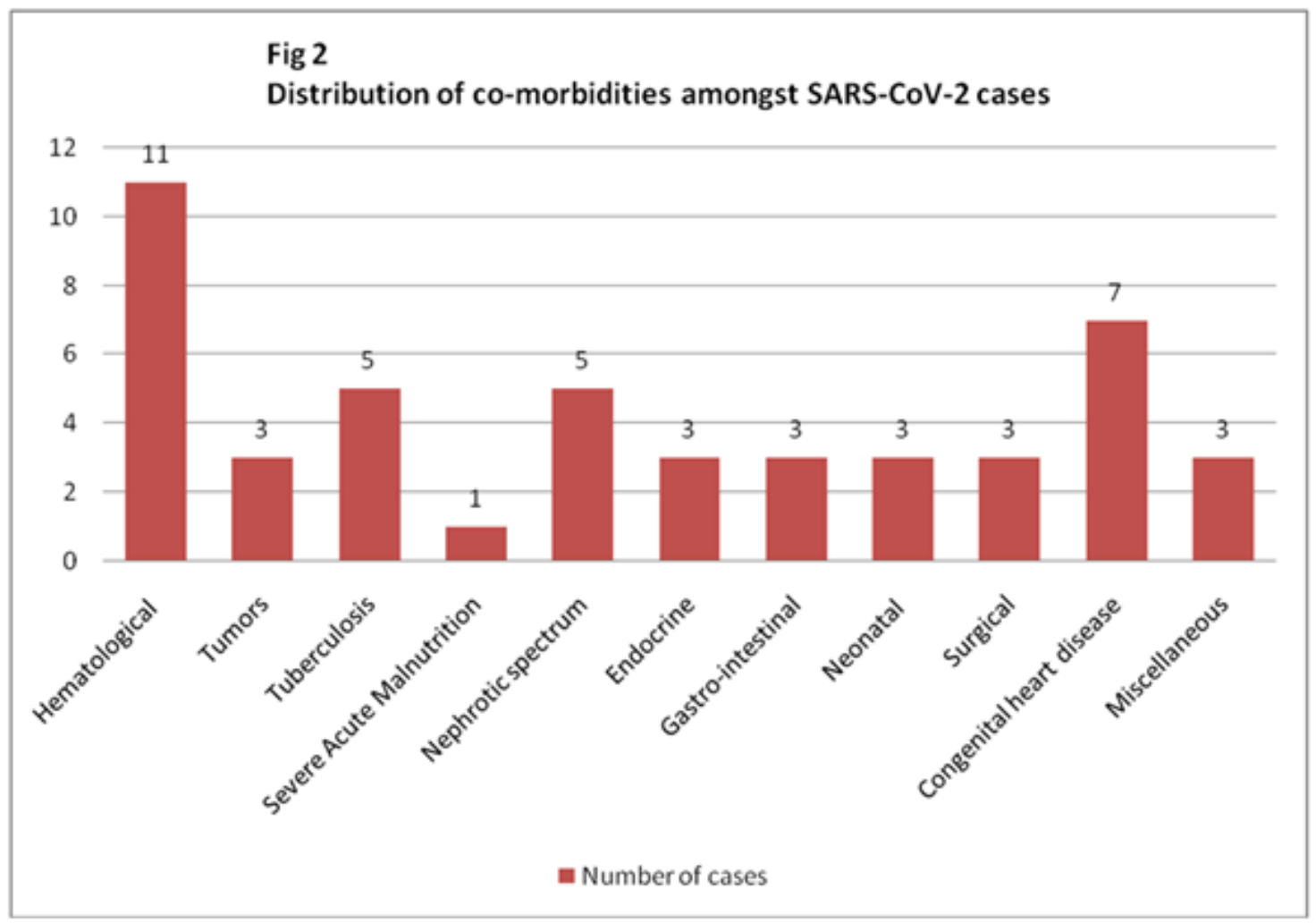

Figure 2

Distribution of co-morbidities amongst SARS-CoV2 cases 